\title{
Thermococcus fumicolans sp. nov., a New Hyperthermophilic Archaeon Isolated from a Deep-Sea Hydrothermal Vent in the North Fiji Basin
}

\author{
ANNE GODFROY ${ }^{1 *}$ JEAN-ROCH MEUNIER,,${ }^{1,2}$ JEAN GUEZENNEC ${ }^{1}$ FRANÇOISE LESONGEUR, ${ }^{1}$ \\ GÉRARD RAGUÉNES, ${ }^{1}$ ALAIN RIMBAULT, ${ }^{3}$ AND GEORGES BARBIER ${ }^{1}$
}

Laboratoire de Biotechnologie, Département Environnement Profond IFREMER, Centre de Brest, 29280 Plouzané, ${ }^{1}$ Unité des Enterobactéries, Institut Pasteur, 75724 Paris cedex $15,^{2}$ and Laboratoire de Microbiologie, Unité Microbiologie Anaérobie, Faculté des Sciences Pharmaceutiques et Biologiques de Paris, Université René Descartes, 75270 Paris cedex 06, ${ }^{3}$ France

\begin{abstract}
An extremely thermophilic archaeon, strain $\mathrm{ST557}^{\mathrm{T}}(\mathrm{T}=$ type strain), was isolated from a deep-sea hydrothermal vent in the North Fiji Basin. This strain is a strictly anaerobic coccus whose cells are about 0.8 to $2 \mu \mathrm{m}$ in diameter. The optimum temperature, $\mathrm{pH}$ and sea salt concentration for growth are $85^{\circ} \mathrm{C}, 8.5$, and 20 to 40 g/liter, respectively. Strain $\mathrm{ST}_{557^{\mathrm{T}}}$ grows preferentially in the presence of elemental sulfur on proteinaceous substrates and on a mixture of 20 amino acids. It grows slowly on pyruvate and maltose. Growth is inhibited by rifampin. The DNA G+C content is 54 to $55 \mathrm{~mol} \%$. Sequencing of the $16 \mathrm{~S}$ rRNA gene revealed

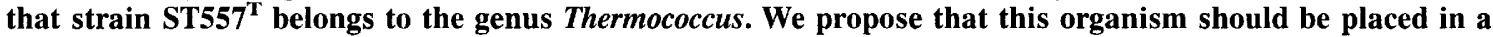
new species, Thermococcus fumicolans.
\end{abstract}

Since the discovery of deep-sea hydrothermal vents in 1977 , a number of hyperthermophiles have been isolated from various sites in the deep sea, including sites on the East Pacific Rise, in the southwest Pacific Ocean and on the Mid-Atlantic Ridge (for a review see reference 39). The deep-sea hyperthermophiles that have been described previously belong to the archaeal domain. These organisms are methanogens belonging to the genera Methanococcus $(23,24)$ and Methanopyrus (28); sulfate reducers, such as Archaeoglobus profundus (7); and sulfur metabolizers, such as members of the genera Staphylothermus (14), Desulfurococcus (21), Pyrococcus (12, 22), Pyrodictium (37), and Thermococcus $(15,20,27)$ and isolated ES1 and ES4 $(35,36)$. Most of the genera mentioned above are not restricted to deep-sea vents, and members of these genera also occur in shallow-water or terrestrial hot spring systems.

During the French-Japanese "Starmer II" cruise in July 1989 in the North Fiji Basin, new hydrothermal sites were explored by the manned submersible "Nautile" (10). At these sites, temperatures up to $288^{\circ} \mathrm{C}$ were measured. During this cruise, many samples (including samples of chimney walls, rock debris, hydrothermal fluid, and animals) were recovered and used to inoculate enrichment cultures for hyperthermophilic sulfur metabolizers that were incubated at 80 and $95^{\circ} \mathrm{C}(1,12)$. In this paper, we describe a new hyperthermophilic heterotrophic archaeal species that was isolated from chimney wall fragments.

\section{MATERIALS AND METHODS}

Reference strains. Thermococcus celer DSM $2476^{\mathrm{T}}$ ( $\mathrm{T}=$ type strain), "Thermococcus litoralis" DSM $5474^{\mathrm{T}}$, Thermococcus stetteri DSM $5262^{\mathrm{T}}$, Pyrococcus furiosus DSM $3638^{\mathrm{T}}$, Pyrococcus woesei DSM $3773^{\mathrm{T}}$, Sulfolobus acidocaldarius DSM $639^{\mathrm{T}}$, and Thermotoga maritima DSM $3109^{\mathrm{T}}$ were obtained from the Deutsche Sammlung von Mikroorganismen, Braunschweig-Stöckeim, Germany. Thermococcus profundus DT5432 $2^{\mathrm{T}}$ was provided by Tetsuo Kobayashi (RIKEN, Wako, Japan), Thermococcus sp. strain ES1 was provided by John Baross (University of Washington, Seattle), and Pyrococcus abyssi GE5 was provided by Gaë Erauso (Centre National de la Recherche Scientifique, Station Biologique de Roscoff, Roscoff, France).

${ }^{*}$ Corresponding author. Mailing address: Laboratoire de Biotechnologie, Département Environnement Profond IFREMER Centre de Brest, BP70, 29280 Plouzané, France.
Culture conditions. 2216-S medium (3) contains (per liter) $2 \mathrm{~g}$ of peptone, $0.5 \mathrm{~g}$ of yeast extract, $30 \mathrm{~g}$ of Sea Salt (Sigma Chemical Co., St. Louis, Mo.), $6.05 \mathrm{~g}$ of PIPES [piperazine- $N, N^{\prime}$-bis(ethanesulfonic acid)] buffer (Sigma), $10 \mathrm{~g}$ of sulfur, and $1 \mathrm{mg}$ of resazurin. BHI-S medium contains (per liter) $9 \mathrm{~g}$ of brain heart infusion, $23 \mathrm{~g}$ of $\mathrm{NaCl}$ (instead of Sea Salt, to prevent formation of a mineral precipitate), $6.05 \mathrm{~g}$ of PIPES buffer, $10 \mathrm{~g}$ of sulfur, and $1 \mathrm{mg}$ of resazurin. 20AA-S medium contains (per liter) $30 \mathrm{~g}$ of Sea Salt, $6.05 \mathrm{~g}$ of PIPES buffer, $10 \mathrm{~g}$ of sulfur, $1 \mathrm{mg}$ of resazurin, $10 \mathrm{ml}$ of a mineral solution (2), and $10 \mathrm{ml}$ of a vitamin solution (2) and each of the 20 classical amino acids at a concentration of $0.2 \mathrm{mM}$. A stock solution containing each of the amino acids at a concentration of $2 \mathrm{mM}$ was sterilized separately by filtration (pore size, $0.22 \mu \mathrm{m}$; Nalgene filterware). Unless indicated otherwise, the $\mathrm{pH}$ was adjusted to 7.5 with $5 \mathrm{~N}$ $\mathrm{NaOH}$. In each case the medium was sterilized by steaming it at $100^{\circ} \mathrm{C}$ for $30 \mathrm{~min}$ on 2 successive days, transferred into an anaerobic chamber containing $\mathrm{N}_{2}, \mathrm{H}_{2}$, and $\mathrm{CO}_{2}(90: 5: 5)$, reduced by adding sodium sulfide to a final concentration of $0.5 \mathrm{~g} /$ liter, and distributed into Hungate tubes or into $50-\mathrm{ml}$ serum vials with butyl rubber stoppers. Unless indicated otherwise, cultures were incubated at atmospheric pressure under the anaerobic chamber gas mixture at $80^{\circ} \mathrm{C}$.

Enrichment cultures and purification. After samples (rock suspensions) were collected, they were stored at room temperature in serum vials filled with sterile seawater under anaerobic conditions $\left(\mathrm{N}_{2}\right.$ headspace gas, $0.5 \mathrm{~g}$ of sodium sulfide per liter). Enrichment cultures were grown on 2216-S medium that was incubated at $80^{\circ} \mathrm{C}$ for 2 or 3 days. Cultures were purified by streaking samples onto 2216-S medium that was solidified with Gelrite (Scott Laboratories, Long Island, N.Y.) and incubated in anaerobic jars at $80^{\circ} \mathrm{C}(11)$. Purified isolates were stored at $4^{\circ} \mathrm{C}$ and could be used as inocula for at least 1 year. For long-term storage, pure cultures were stored anaerobically at $-70^{\circ} \mathrm{C}$ in the presence of $5 \%$ (wt/vol) dimethyl sulfoxide (Sigma) as a cryoprotectant.

Determination of cells number. The numbers of cells in liquid cultures were determined by direct visual counting. Samples were diluted in sterile water containing Sea Salt $(30 \mathrm{~g} /$ liter $)$, formalin $(2.5 \%)$, and acridine orange $(0.01 \%)$, filtered with black polycarbonate membrane filters (pore size, $0.2 \mu \mathrm{m}$; Nucleopore), and examined with an Olympus model BH-2 microscope (19).

Determination of growth parameters. To determine the optimum temperature, cells were grown in Hungate tubes containing $6 \mathrm{ml}$ of 2216-S medium. The headspace gas was $\mathrm{N}_{2}-\mathrm{CO}_{2}-\mathrm{H}_{2}(90: 5: 5)$ at a pressure of $100 \mathrm{kPa}$ for temperatures under $100^{\circ} \mathrm{C}$ and at a pressure of $200 \mathrm{kPa}$ for temperatures of $100^{\circ} \mathrm{C}$ or more. Temperatures were maintained with aluminum heating blocks (Bioblock, Illkirch, France) and were monitored with temperature probes placed in control tubes. To determine growth rates at different $\mathrm{pHs}, 2216-\mathrm{S}$ medium was modified by using the following buffers (Sigma), each at a concentration of $1 \mathrm{~g} /$ liter: for $\mathrm{pH}$ $2.5,3.5$, and 4.5 , no buffer; for $\mathrm{pH}$ 5.5, MES (morpholineethanesulfonic acid) buffer; for $\mathrm{pH}$ 6.5, PIPES buffer; for $\mathrm{pH} 7.5$, HEPES ( $N$-2-hydroxyethylpiperazine- $N^{\prime}$-2-ethanesulfonic acid) buffer; and for $\mathrm{pH} 8.5$ and 9.5, AMPSO $\{[3-(1,1-$ Dimethyl-2-hydroxyethyl)amino]-2-hydroxypropanesulfonic acid $\}$ buffer. After sodium sulfide was added, the $\mathrm{pH}$ was adjusted with $1 \mathrm{M} \mathrm{HCl}$. To determine the salt requirement, 2216-S medium was prepared with different dilutions of Sea Salt. The effects of $\mathrm{pH}$ and salinity were determined at $80^{\circ} \mathrm{C}$. Three replicates were studied simultaneously at each temperature, $\mathrm{pH}$, or level of salinity.

Determination of growth requirements. The ability of isolate $\mathrm{ST} 557^{\mathrm{T}}$ to utilize 
various carbon sources was determined in media in which the yeast extract and peptone of $2216-\mathrm{S}$ medium were replaced by $0.4 \mathrm{~g}$ of ammonium chloride per liter, $10 \mathrm{ml}$ of a mineral solution (2) per liter, $10 \mathrm{ml}$ of a vitamin solution (2) per liter, and carbon sources. The tests were performed by using tubes containing no nitrogen and carbon sources as controls for growth on the inoculum. Most of the carbon sources were tested at a concentration of $5 \mathrm{~g} /$ liter; the exceptions were starch, cellulose, and chitin, which were tested at a concentration of $10 \mathrm{~g} / \mathrm{liter}$, and ethanol, which was tested at a concentration of $5 \mathrm{ml} /$ liter. Growth on BHI-S medium and growth on 20AA-S medium were also tested. In addition, autotrophic growth under $\mathrm{H}_{2}-\mathrm{CO}_{2}(80: 20)$ headspace gas as the sole carbon source was tested. To determine the ability of the isolate to grow in the absence of elemental sulfur, cells were cultured on 2216-S medium from which sulfur compounds had been omitted; in these experiments the headspace gas was $\mathrm{N}_{2}, \mathrm{~N}_{2}-\mathrm{CO}_{2}(80: 20)$, or $\mathrm{H}_{2}-\mathrm{CO}_{2}(80: 20)$ at a pressure of $100 \mathrm{kPa}$, and the medium was reduced by titanium nitrilotriacetate (32) at a concentration of $200 \mu \mathrm{M}$. To determine $\mathrm{H}_{2} \mathrm{~S}$ production, an uninoculated control was grown, and samples were immediately analyzed for $\mathrm{H}_{2} \mathrm{~S}$ production by the colorimetric method of Cline (8). To determine the ability of the isolate to use a range of electron acceptors, elemental sulfur was replaced by potential electron acceptors at a concentration of $1 \mathrm{mM}$. Growth on cystine $(10 \mathrm{~g} /$ liter $)$ and growth on polysulfide $(10 \mathrm{mM})(6)$ were also investigated.

Antibiotic susceptibility. Susceptibility to the antibiotics vancomycin, penicillin, kanamycin, streptomycin, rifampin, and chloramphenicol at final concentrations of 50,100 , and $150 \mu \mathrm{g} / \mathrm{ml}$ was determined under the standard growth conditions. The bacterium Thermotoga maritima was used as a control to establish the effectiveness of antibiotics at $80^{\circ} \mathrm{C}$.

Electron microscopy. Cells were harvested at the end of the log phase. For transmission electron microscopy, pellets were resuspended and fixed for $1 \mathrm{~h}$ at room temperature in $0.4 \mathrm{M}$ cacodylate buffer ( $\mathrm{pH} 7.4)-5.5 \%$ (wt/vol) $\mathrm{NaCl}-8 \%$ (vol/vol) glutaraldehyde $(2: 1: 1)$ and then postfixed for $1 \mathrm{~h}$ at $4^{\circ} \mathrm{C}$ in $0.4 \mathrm{M}$ cacodylate buffer (pH 7.4)-10\% (wt/vol) NaCl-2\% (wt/vol) $\mathrm{OsO}_{4}(1: 1: 2)$. After dehydration with increasing ethanol concentrations, cells were embedded in Spurr's resin, thin sectioned, contrasted with $1 \%$ (wt/vol) uranyl acetate and $1 \%$ (wt/vol) lead citrate (Bio-Rad S.A., Ivry, France), and examined with a model EM201 transmission microscope (Philips, Eindhoven, The Netherlands).

For scanning electron microscopy, cells were fixed with $7 \%$ (wt/vol) glutaraldehyde and then filtered with a $0.22-\mu \mathrm{m}$-pore-size Nuclepore filter. After salt was eliminated and the preparation was dehydrated with increasing ethanol concentrations, samples were critical point dried, coated with gold (catalog no. SCD 040; Balzers, Balzers, Liechtenstein), and examined with a Cambridge Stereoscan $\mathrm{S} 100$ microscope.

Lipid analysis. (i) Lipid extraction. Lipids were extracted from lyophilized cells $(50$ to $100 \mathrm{mg})$ by using a modified Bligh-Dyer method $(4,45)$. The extracted lipids were fractionated into neutral lipids, glycolipids, and polar lipids by silicic acid column chromatography by using chloroform, acetone, and methanol, respectively. The methanol fraction containing polar ethers was dried under a vacuum and stored under $\mathrm{N}_{2}$ until further analysis.

(ii) Glycerol ether analysis. The polar phase of the Bligh-Dyer extraction preparation was subjected to strong acid hydrolysis, and the resulting core ether lipids were digested with $55 \% \mathrm{HI}$ for $18 \mathrm{~h}$ at $100^{\circ} \mathrm{C}$. The resulting alkyl iodide were extracted with hexane and successively washed with $\mathrm{Na}_{2} \mathrm{~S}_{2} \mathrm{O}_{3}$ and $\mathrm{Na}_{2} \mathrm{CO}_{3}$ solutions $(25,29,34)$. After extraction with hexane, the iodide derivatives were analyzed with a gas chromatograph equipped with an electron capture detector by using 1,2 di-o-hexadecyl-rac-glycerol as the internal standard. Authentic glycerol diethers and diglycerol tetraethers were purchased from Sigma or were isolated from Sulfolobus acidocaldarius.

Organic acid production. The isolate was grown on BHI-S medium and on $20 \mathrm{AA}-\mathrm{S}$ medium at $80^{\circ} \mathrm{C}$ for $15 \mathrm{~h}$. Organic acids were analyzed by gas chromatography and by gas chromatography-mass spectrometry as ter-butyl dimethylsilyl derivatives (40)

DNA base composition. Cells were cultured in 4.5 liters of $2216-\mathrm{S}$ medium at $80^{\circ} \mathrm{C}$ and were harvested at the end of the exponential phase of growth. After centrifugation, the cell pellet was suspended in $5 \mathrm{ml}$ of lysis buffer $(100 \mathrm{mM}$ Tris- $\mathrm{HCl}, 100 \mathrm{mM} \mathrm{NaCl}, 0.50 \mathrm{mM}$ EDTA; $\mathrm{pH} 8$ ), $1 \%$ (wt/vol) Sarkosyl was added, and then $1 \%$ (wt/vol) sodium dodecyl sulfate and proteinase $\mathrm{K}$ (final concentration, $0.4 \mathrm{mg} / \mathrm{liter}$ ) were added for cell lysis. After $3 \mathrm{~h}$ of incubation at $40^{\circ} \mathrm{C}$, three phenol-chloroform-isoamyl alcohol $(24: 24: 1)$ extraction and one chloroform extraction were performed. The DNA was precipitated by adding 2 volumes of ethanol at $-20^{\circ} \mathrm{C}$. The DNA pellet was resuspended in TE $(10 \mathrm{mM}$ Tris- $\mathrm{HCl}, 2 \mathrm{mM}$ EDTA [pH 7.4]) buffer and treated with RNase (5 $\mu \mathrm{g} / \mathrm{liter})$ for $1 \mathrm{~h}$ at $60^{\circ} \mathrm{C}$. The DNA base composition was determined by high-performance liquid chromatography (HPLC) at the Deutsche Sammlung von Mikroorganismen Identification Service and by the thermal denaturation method (30).

Qualitative DNA-DNA hybridization (dot blots). DNAs $(0.15 \mu \mathrm{g})$ extracted from reference strains and strain ST557 ${ }^{\mathrm{T}}$ were applied to a nylon membrane (Hybond N; Amersham, Amersham Place, United Kingdom) by using a manifold attached to a suction device. The DNAs had been denatured previously by treating them with $\mathrm{NaOH}$ (final concentration, $0.1 \mathrm{M}$ ) for $5 \mathrm{~min}$ and had been neutralized with $\mathrm{Na}_{2} \mathrm{HPO}_{4}$ (final concentration, $0.1 \mathrm{M}$ ). The DNAs were immobilized on the nylon membrane by using UV irradiation and then hybridized with peroxidase-labelled ST557 $7^{\mathrm{T}}$ DNA as the probe (ECL direct labelling kit; Amersham).

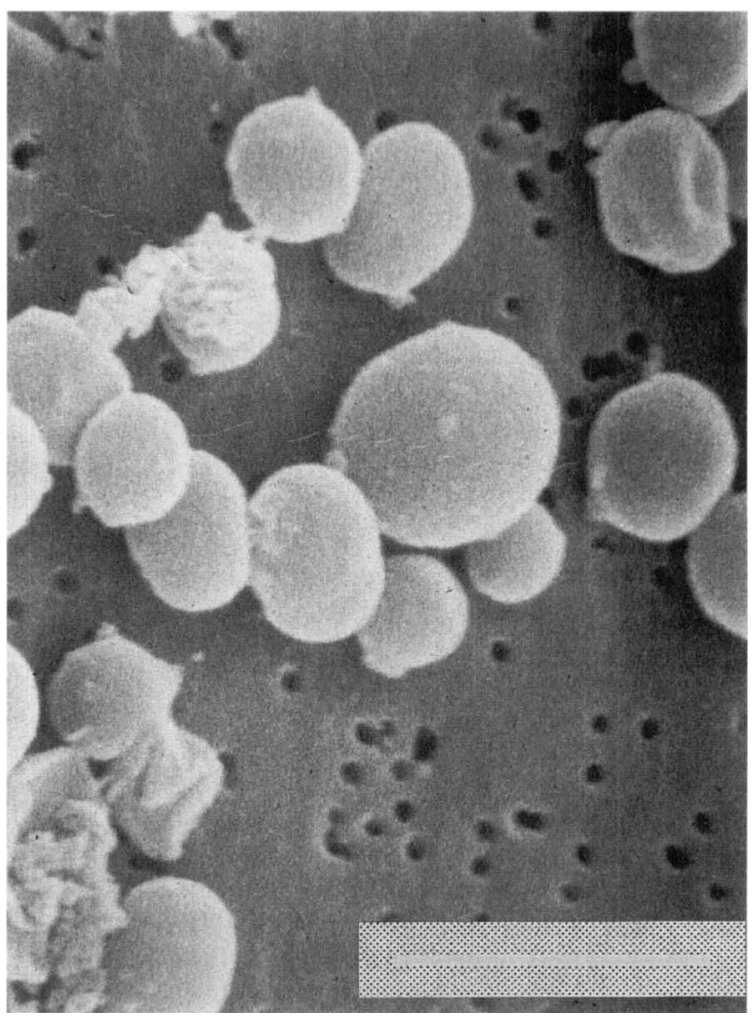

FIG. 1. Scanning electron micrograph of strain $\mathrm{ST} 557^{\mathrm{T}}$. Bar $=2 \mu \mathrm{m}$.

16S rRNA gene sequence analysis. The $r r s$ gene was amplified by the PCR (41) as described previously (9) except that "archaean"-specific primers were used. The PCR products were cloned into pUC18 vectors by using a SureClone ligation kit (Pharmacia, Uppsala, Sweden) and were subcloned as HindIII-EcoRI insertions into M13mp18 and M13mp19 vectors. Both strands of one clone were sequenced by the dideoxy chain termination method (43), except that we used a HotTub DNA sequencing kit to resolve numerous compressions observed when genes of hyperthermophilic microorganisms were sequenced. PCR products were also directly sequenced by using a cycle sequencing kit (type CSDS; Gibco BRL, Gaithersburg, Md.) and ${ }^{32}$ P-labelled primers (Amersham). A total of 1,309 $b p$ were sequenced. The sequences which we determined were then aligned with a representative collection of reference $16 \mathrm{~S}$ rRNA sequences. A multiple alignment, a phylogenetic tree, and levels of similarity were obtained by using the MegAlign program of the DNASTAR package (Promega, Madison, Wis.) (Clustal method with weighted residue, weight table PAM 250) and the neighbor-joining method (42).

Quantitative DNA-DNA hybridization. The DNAs of the Thermococcus celer and "Thermococcus litoralis" reference strains were used as labelled probes. Up to 20 liters of a culture were needed to get enough DNA for the experiment. A 4- to 5- $\mu \mathrm{g}$ portion of each reference strain DNA was labelled by incorporating both $\left[{ }^{3} \mathrm{H}\right] \mathrm{dATP}$ and $\left[{ }^{3} \mathrm{H}\right] \mathrm{dGTP}$ with a Megaprime kit (Amersham). The nuclease S1 method of quantitative DNA-DNA hybridization was performed as described by Popoff and Coynault (38) on type DE81 filters (Whatman International, Maidstone, United Kingdom) by using a Bmatic IV scintillation counter (Kontron Instruments, Montigny le Bretonneux, France).

Nucleotide sequence accession number. The nucleotide sequence of the $16 \mathrm{~S}$ rRNA of strain ST557 ${ }^{\mathrm{T}}$ has been deposited in the GenBank database under accession number Z70250.

\section{RESULTS}

Collection of samples. Small pieces of rocks and chimney walls were obtained by using the manned submersible "Nautile" at the White Lady hydrothermal site in the North Fiji Basin (16 $59^{\prime} \mathrm{S}, 173^{\circ} 55^{\prime} \mathrm{W}$; depth, 2,000 m) (10) during the French-Japanese "Starmer II" cruise in July 1989. At this site, active chimneys are composed mainly of anhydrite (16), and fluid temperatures up to $288^{\circ} \mathrm{C}$ were measured.

Enrichment and purification. Enrichment cultures were 

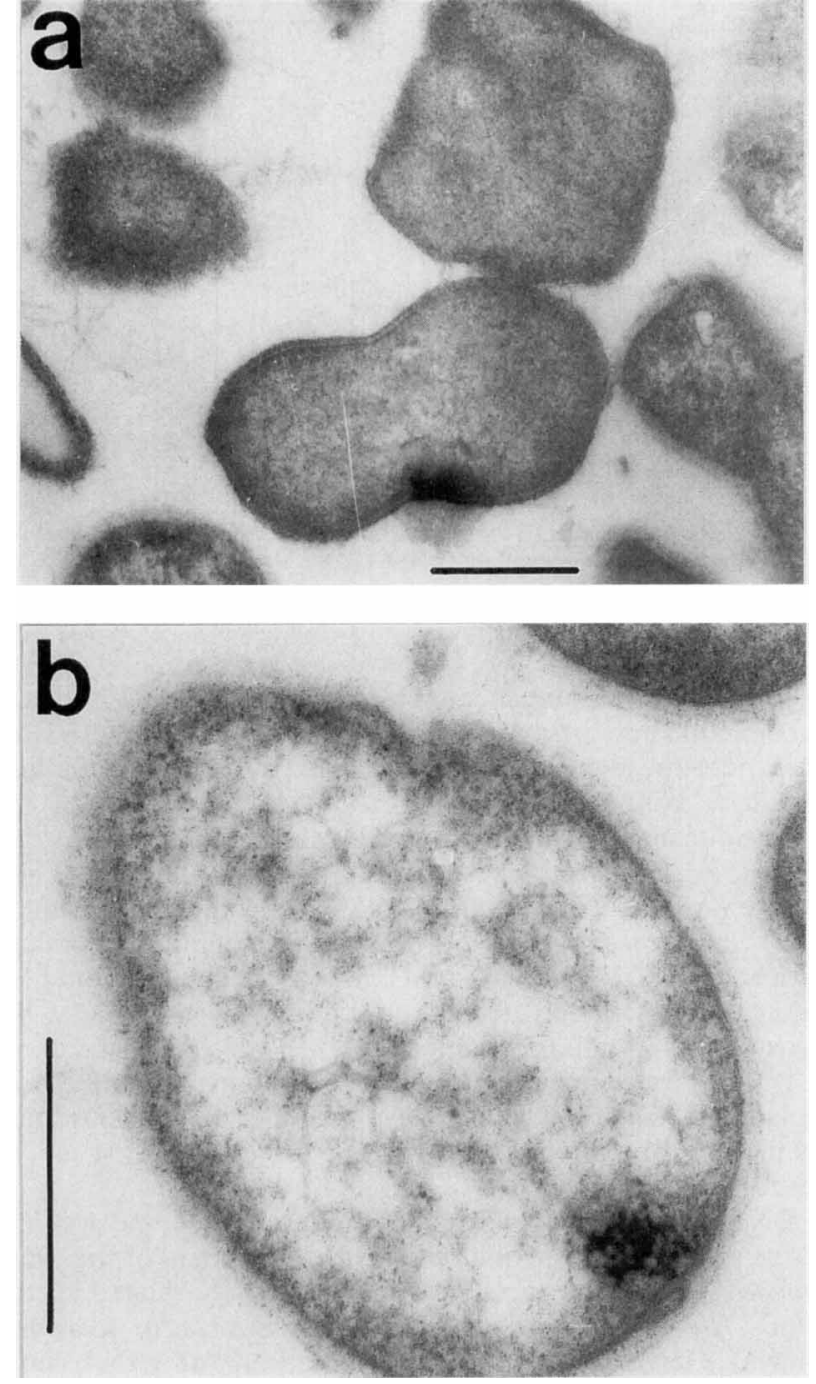

FIG. 2. Transmission electron micrographs of strain $\mathrm{ST} 557^{\mathrm{T}}$. Bars $=1 \mu \mathrm{m}$.

grown on $2216-\mathrm{S}$ medium at $80^{\circ} \mathrm{C}$. After 2 or 3 days increases in turbidity and microscopic observations indicated that growth had occurred. Purification was performed by plating samples on solid sulfur-containing medium. A total of 16 isolates were obtained. The $\mathrm{G}+\mathrm{C}$ contents of these organisms were determined by the thermal denaturation method and ranged from 52 to $59 \mathrm{~mol} \%$. A preliminary study of growth temperatures (data not shown) revealed that one isolate, strain $\mathrm{ST} 557^{\mathbf{T}}$, exhibited rapid growth at temperatures of $90^{\circ} \mathrm{C}$ or more. This isolate was chosen for further study.

Morphology. Scanning electron microscopy (Fig. 1), transmission electron microscopy (Fig. 2), and phase-contrast microscopy (data not shown) revealed that isolate ST55 $7^{\mathrm{T}}$ cells were coccoid and occurred singly, in pairs, or in small aggregates. The cell size ranged from 0.8 to $2 \mu \mathrm{m}$. The cells appeared to be motile, and polar flagella were observed by phasecontrast microscopy after specific coloration with Spot Test flagellum stain (Difco Laboratories, Detroit, Mich.). Cells most likely divided by constriction, as indicated by electron micrographs (Fig. 2a). Thin sections revealed a two-layer cell envelope (Fig. 2b).

Antibiotic susceptibility. The control bacterium Thermotoga maritima exhibited the expected pattern of antibiotic susceptibility at a high temperature, demonstrating that the antibiotics utilized in this study were not deactivated by heating. Isolate ST557 ${ }^{\mathrm{T}}$ was resistant to vancomycin, penicillin, kanamycin, streptomycin, and chloramphenicol at concentrations up to 150 $\mu \mathrm{g} / \mathrm{ml}$ but was susceptible to rifampin at concentration of 100 and $150 \mu \mathrm{g} / \mathrm{ml}$.

Lipid analysis. The polar lipid fraction of strain ST557 ${ }^{\mathrm{T}}$ consisted of glycerol ether lipids, with diphytanyl glycerol diether $\left(\mathrm{C}_{20}\right)$ accounting for $70 \%$ of the total lipids. In the residual phase of the Bligh-Dyer extraction preparation the glycerol tetraethers having various proportions of cyclopentane rings predominated along with small amount of diethers. The proportions of the acyclic, monocyclic, and bicyclic tetraethers were estimated to be 60,20 , and $20 \%$ of the total ethers, respectively.

Determination of growth parameters. Isolate $\mathrm{ST} 557^{\mathrm{T}}$ grew at 73 to $103^{\circ} \mathrm{C}$, and the optimum temperature for growth was 85 to $90^{\circ} \mathrm{C}$ (Fig. 3a). Growth was observed at $\mathrm{pH} 4.5$ to 9.5 , and the optimum $\mathrm{pH}$ was near 8 ; no growth was observed at $\mathrm{pH} 3.5$ (Fig. 3b). Growth was observed at salt concentrations ranging from 10 to $80 \mathrm{~g} / \mathrm{liter}$, and the optimum salt concentration was between 20 and $40 \mathrm{~g} /$ liter (corresponding to 13 to $26 \mathrm{~g}$ of $\mathrm{NaCl}$ per liter); no growth was detected at salt concentrations of 5 and $100 \mathrm{~g}$ /liter (Fig. 3c).

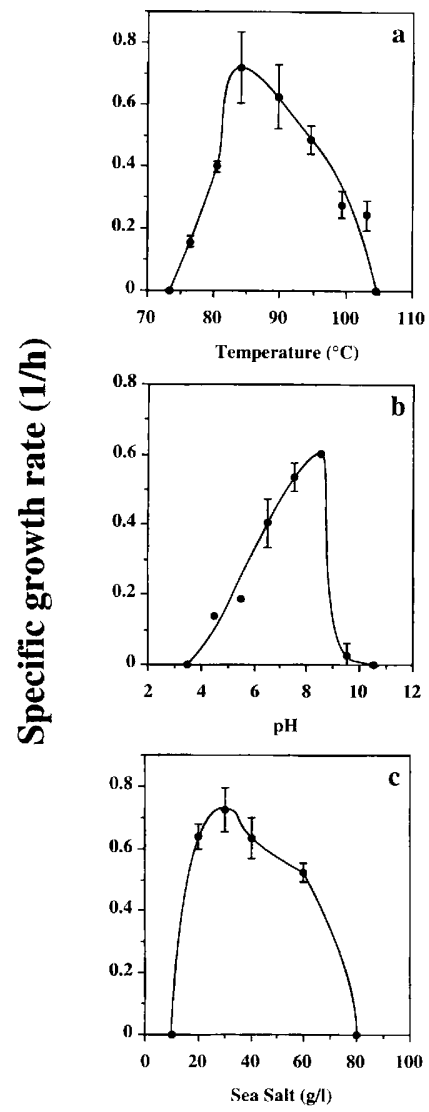

FIG. 3. Temperature, $\mathrm{pH}$, and Sea Salt concentration optima for growth of isolate ST557 $7^{\mathrm{T}}$ on 2216-S medium. Specific growth rates are plotted as a function of temperature (in the presence of $30 \mathrm{~g}$ of Sea Salt per liter at $\mathrm{pH} 7.5)(\mathrm{a}), \mathrm{pH}$ (in the presence of $30 \mathrm{~g}$ of Sea Salt per liter at $80^{\circ} \mathrm{C}$ ) (b), and salinity (at $80^{\circ} \mathrm{C}$ and $\mathrm{pH} 7.5)$ (c). Growth rates were calculated by performing a linear regression analysis along the logarithmic part of the growth curves. If enough data were available, information about the precision of the growth rate is given (regression coefficient \pm 2 standard errors). 
TABLE 1. Growth requirements of strain ST557 $7^{\mathrm{T}}$ : carbon sources and electron acceptors

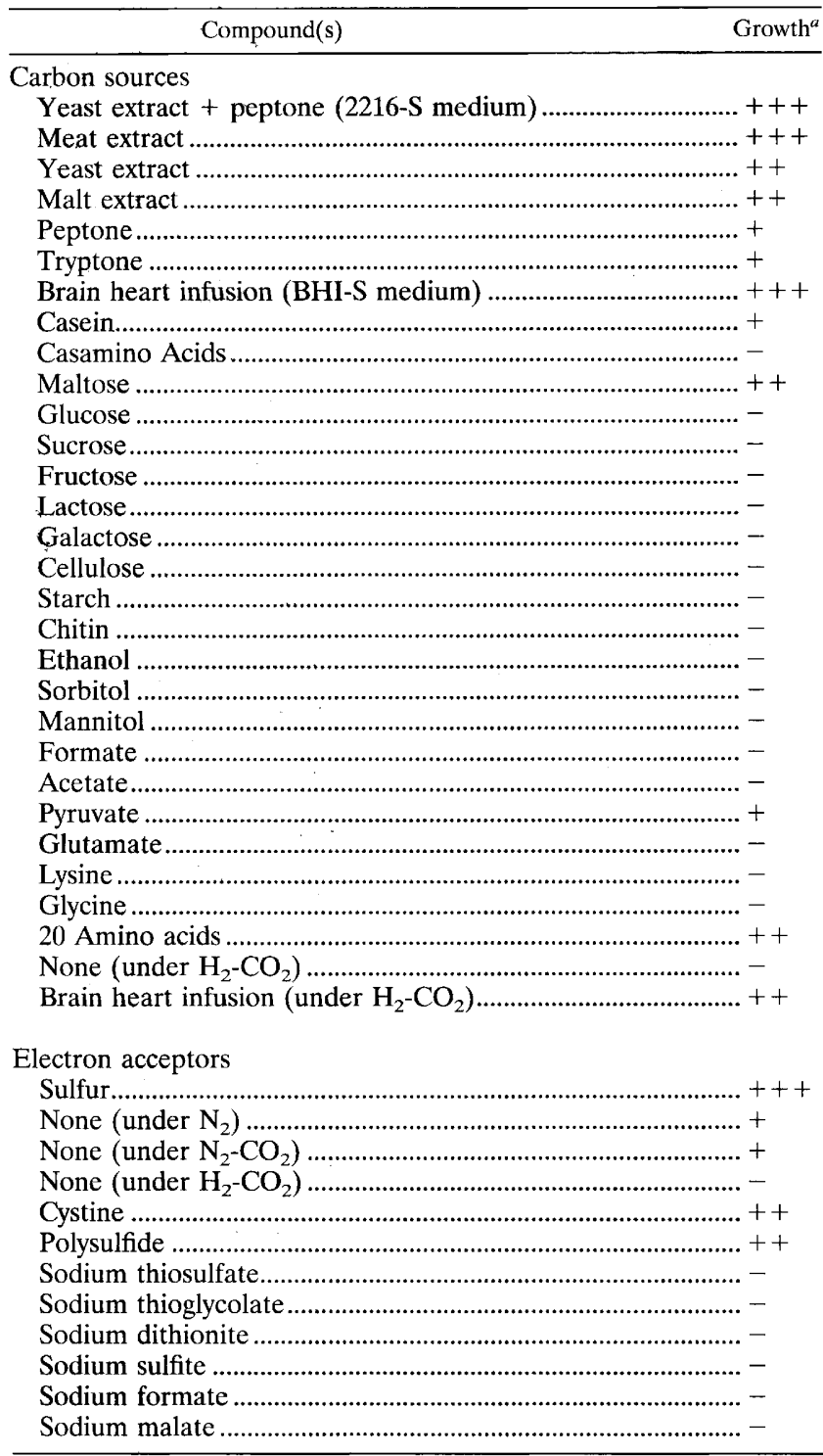

${ }^{a}+++,>2 \times 10^{8}$ cells per $\mathrm{ml}$ of culture (final concentration);,$++ 5 \times 10^{7}$ to $2 \times 10^{8}$ cells per ml of culture (final concentration);,$+ 1.5 \times 10^{7}$ to $5 \times 10^{7}$ cells per $\mathrm{ml}$ of culture (final concentration); - , no growth.

Determination of growth requirements. 2216-S medium supported rapid growth of isolate $S T 557^{\mathrm{T}}$. Yeast extract-peptone could be replaced by several complex substrates, including tryptone, yeast extract, meat extract, peptone, brain heart infusion, malt extract, and casein. Significant growth was also observed when the 20 amino acids were used as a carbon source. Maltose and pyruvate supported slow growth, but none of the other sugars, alcohols, carboxylic acids, individual amino acids, or polysaccharides tested supported growth of ST557 ${ }^{\mathrm{T}}$. $\mathrm{H}_{2}-\mathrm{CO}_{2}(80: 20)$ headspace gas did not support autotrophic growth and decreased the growth rate of ST557 $7^{\mathrm{T}}$ on BHI-S medium (Table 1). Very slow growth occurred in the absence of elemental sulfur, and growth was rapidly inhibited by $80 \%$ $\mathrm{H}_{2}$ (Fig. 4). Cystine and polysulfide supported rapid growth of ST557 $7^{\mathrm{T}}$, but none of the other electron acceptors tested supported growth of ST557 $7^{\mathrm{T}}$ (Table 1). When elemental sulfur was

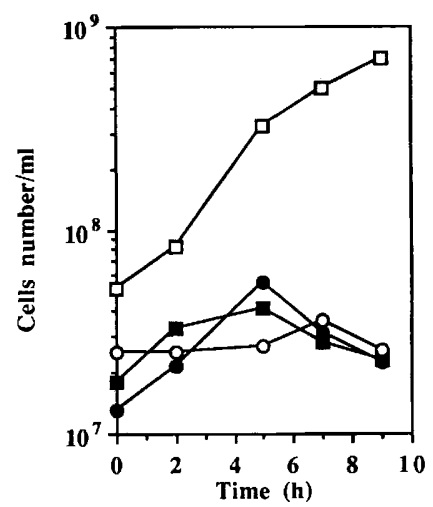

FIG. 4. Growth of strain ST557 $7^{\mathrm{T}}$ in the absence of elemental sulfur. Symbols: -, growth under $\mathrm{N}_{2} ; \mathbf{E}$, growth under $\mathrm{N}_{2}-\mathrm{CO}_{2}(80: 20) ; \mathrm{O}$, growth under $\mathrm{H}_{2}-\mathrm{CO}_{2}$ (80:20); $\square$, growth in the presence of sulfur under $\mathbf{N}_{2}$.

present in the culture medium, growth of strain ST557 ${ }^{\mathbf{T}}$ was accompanied by the production of large amounts of $\mathrm{H}_{2} \mathrm{~S}$ (Fig. 5). Under these conditions $\mathrm{H}_{2} \mathrm{~S}$ was not produced in the uninoculated control.

Organic acid production. In BHI-S and 20AA-S media, acetate (5.4 and $4.7 \mathrm{mM}$, respectively), phenylacetate (3.03 and $0.87 \mathrm{mM})$, lactate $(1.13$ and $1.47 \mathrm{mM})$, and 2 methylpropionate (2.97 and $0.61 \mathrm{mM}$ ) were the major fermentation products; propanoate $(1.14$ and $0.67 \mathrm{mM})$, indole acetate $(0.31$ and 0.4 $\mathrm{mM}), 3$-methylthiopropanoate $(1.0$ and $0.43 \mathrm{mM})$, and $p$-hydroxyphenylacetate $(0.58$ and $0.25 \mathrm{mM})$ were also present.

DNA bases composition. The $\mathrm{G}+\mathrm{C}$ contents of the DNA of isolate $S T 557^{\mathrm{T}}$ determined by the thermal denaturation method and by direct HPLC analysis were 55 and $54 \mathrm{~mol} \%$, respectively.

DNA-DNA homology. Strain ST557 $7^{\mathbf{T}}$ exhibited only low levels of similarity to previously described members of the Thermococcales and appeared to be more closely related to the genus Thermococcus than to the genus Pyrococcus (data not shown). On the phylogenetic tree based on 16S rRNA genes sequences (see below) the levels of similarity were quantified by using Thermococcus celer and "Thermococcus litoralis," which exhibited average levels of homology of 22 and $15 \%$ with strain ST557 ${ }^{\mathrm{T}}$, respectively.

$16 \mathrm{~S}$ rRNA sequence analysis. The sequence of the $16 \mathrm{~S} \mathrm{rR}$ NA-encoding gene of strain ST557 $7^{\mathrm{T}}$ was determined and aligned with the other available archaeal 16S rRNA sequences. A comparison of the $16 \mathrm{~S}$ rRNA sequences in which a phylo-

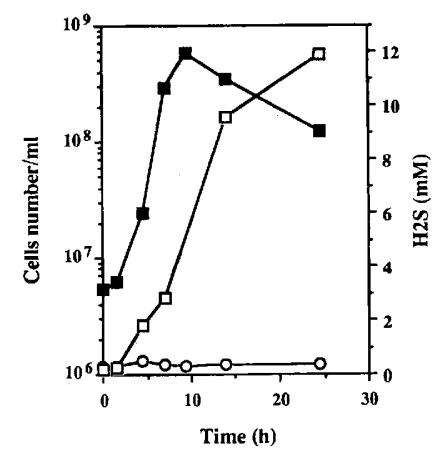

FIG. 5. Growth of and sulfide production by strain ST557 $7^{\mathrm{T}}$ cultivated at $80^{\circ} \mathrm{C}$ on 2216-S medium. Symbols: $\square$, growth; $\square$, sulfide production; $\bigcirc$, uninoculated control. 


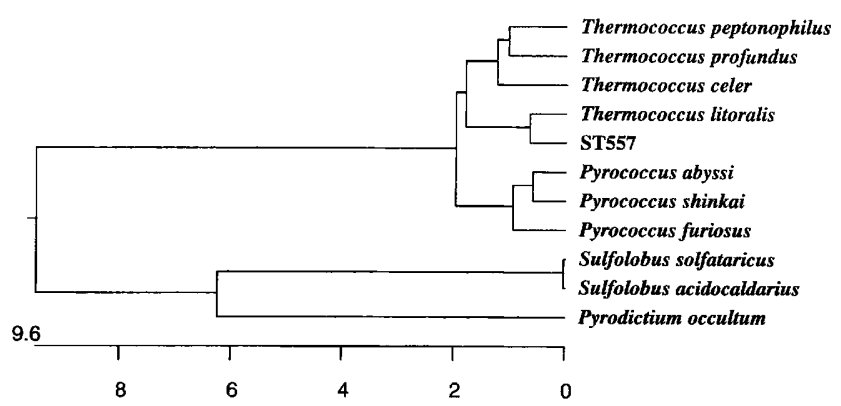

FIG. 6. Phylogenetic relationships based on $16 \mathrm{~S}$ rRNA sequences. Most $16 \mathrm{~S}$ rRNA sequences were obtained from the GenBank and EMBL databases. The exceptions were the sequences of "Thermococcus litoralis," and Thermococcus profundus, which were determined in this study. The units for the scale are the number of substitution events inferred. The accession numbers of the sequences of the organisms used in this analysis are as follows: Thermococcus celer, M21529I; "Thermococcus peptonophilus," D37982; Pyrococcus abyssi, L19921; Pyrococcus shinkai, D45214; Pyrococcus furiosus, U20163; Pyrodictium occultum, M21087; Sulfolobus solfataricus, X03235; Sulfolobus acidocaldarius, D14876; "Thermococcus litoralis," Z70251; and Thermococcus profundus, 275233.

genetic tree was constructed (Fig. 6) revealed that strain ST55 $7^{\mathbf{T}}$ belongs to the order Thermococcales, which includes two genera, the genera Pyrococcus and Thermococcus (5). The levels of similarity between the $16 \mathrm{~S}$ rRNA of ST557 ${ }^{\mathrm{T}}$ and the 16S rRNAs of other Thermococcus species are as follows: Thermococcus celer, 89.2\%; "Thermococcus litoralis," 90.8\%; Thermococcus profundus, $88.5 \%$; and "Thermococcus peptonophilus," $86.4 \%$. The results of this analysis clearly indicate that strain ST557 ${ }^{\mathrm{T}}$ belongs to the genus Thermococcus and represents a new species of this genus.

\section{DISCUSSION}

Novel marine hyperthermophilic strain ST557 ${ }^{\mathrm{T}}$ belongs to the archaeal domain on the basis of its resistance to antibiotics, the presence of di- and tetraether lipids, and its 16S rRNA sequence. On the basis of its $\mathrm{G}+\mathrm{C}$ content, DNA-DNA hybridization data, and its $16 \mathrm{~S}$ rRNA sequence, strain $\mathrm{ST} 557^{\mathrm{T}}$ clearly belongs to the genus Thermococcus. This classification is consistent with the morphological and physiological characteristics of strain ST557 ${ }^{\mathrm{T}}$, which are similar to the characteristics of this genus. Strain ST557 ${ }^{\mathbf{T}}$ resembles "Thermococcus litoralis," Thermococcus stetteri, Thermococcus profundus, and "Thermococcus peptonophilus" in its susceptibility to $100 \mu \mathrm{g}$ of rifampin per ml. Like "Thermococcus litoralis," strain ST557 ${ }^{\mathrm{r}}$ grows slowly on pyruvate but clearly differs from this species and from the recently described species "Thermococcus alcaliphilus" (26) and "Thermococcus chitonophagus" (20) in its DNA G + C content. Strain ST557 ${ }^{\mathrm{T}}$ resembles "Thermococcus peptonophilus" in its temperature range for growth and Thermococcus profundus in its physiological characteristics ( $\mathrm{pH}$ and salinity ranges for growth and growth on pyruvate and maltose) but clearly differs from these organisms in its ability to grow at temperatures above $100^{\circ} \mathrm{C}$. ST $557^{\mathrm{T}}$ differs from the other previously described Thermococcus species in its optimum $\mathrm{pH}$ (around $\mathrm{pH} 8$ ) and temperature range for growth. Characteristics of Thermococcus species are summarized in Table 2. Optimal growth occurs in the presence of proteinaceous substrates, and ST557 $7^{\mathrm{T}}$ is able to grow on a mixture of 20 amino acids as a sole carbon and energy source. The ability to grow under these conditions has been reported previously for Pyrococcus abyssi $(12,44)$, for Pyrococcus sp. strain ES4 (36), for Desulfurococcus sp. strain SY, for Pyrococcus sp. strain GB-D

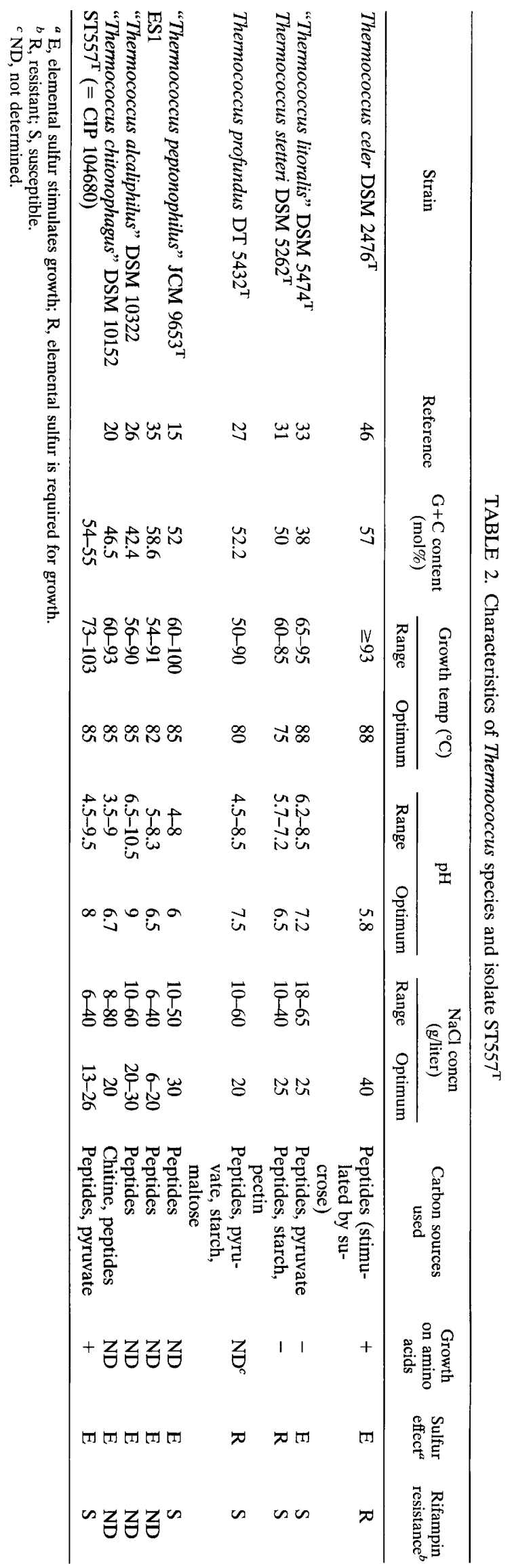


(18), and for Thermococcus sp. isolates KS1, KS2, and KS8 (17) and has been observed for other members of the Thermococcales isolated from deep-sea hydrothermal ecosystems (14a). The ability to utilize amino acids could be related to the organic matter available in the hydrothermal ecosystems. Growth occurs on maltose and pyruvate, but small amounts of complex organic compounds (such as the brain heart infusion added with the inoculum) seem to be required as no growth was observed after successive cultures on media containing maltose and pyruvate (data not shown). Growth of strain ST557 $7^{\mathrm{T}}$ is not strictly dependent on elemental sulfur, but elemental sulfur greatly enhances the growth of strain ST557 ${ }^{\mathrm{T}}$; elemental sulfur can be replaced by cystine or polysulfide, but growth is slower. In the absence of elemental sulfur, the growth yields are low; this is apparently due to inhibition by $\mathrm{H}_{2}$ that evolves as an end product, as reported previously for Pyrococcus furiosus (13) and Pyrococcus abyssi (12).

On the basis of its physiological characteristics, its $16 \mathrm{~S}$ rRNA sequence, and DNA-DNA hybridization data, new isolate $\mathrm{ST} 557^{\mathrm{T}}$ represents a new species of the genus Thermococcus; this species is named Thermococcus fumicolans because it was isolated from smoker wall pieces collected at deep-sea hydrothermal vents. Thermococcus fumicolans is the most thermophilic species in the genus Thermococcus (temperature range for growth, 73 to $103^{\circ} \mathrm{C}$ ).

Description of Thermococcus fumicolans sp. nov. Thermococcus fumicolans Godfroy and Meunier (fu.mi.co.lans. L. m. n. fumus, smoke, referring to the smokers or chimneys of deepsea vents; L. partic. pres. colans, living on; M. L. adj. fumicolans, living on smoke). Cells are spherical cocci (diameter, 0.8 to $2 \mu \mathrm{m}$ ) that are motile by means of polar tufts of flagella. Cell division occurs by constriction. Obligately anaerobic. Grows optimally in the presence of 20 to $40 \mathrm{~g}$ of Sea Salt per liter and at a $\mathrm{pH}$ around 8 . The temperature range for growth is 73 to $103^{\circ} \mathrm{C}$, and the optimum temperature is around $85^{\circ} \mathrm{C}$. Obligately chemoorganotrophic. Grows on proteolysis products and a mixture of amino acids. Sulfur is not necessary for growth but greatly enhances growth. The results of $16 \mathrm{~S}$ rRNA sequence comparisons place Thermococcus fumicolans in the Thermococcales. Type strain ST557 (= CIP 104680 [Collection de l'Institut Pasteur, Paris, France]) was isolated from an active chimney wall fragment obtained at a hydrothermal site in the North Fiji Basin in the southwest Pacific Ocean.

\section{ACKNOWLEDGMENTS}

We thank the cochief scientists of the French-Japanese "Starmer II" cruise, Daniel Desbruyères and Suguru Otha, for inviting one of us to participate in the cruise. Anne-Lise Tredan is gratefully acknowledged for her important contribution to this work. We thank Philippe Crassous for performing scanning electron microscopy, Françoise Gaill and Lahcen Hamraoui for performing transmission electron microscopy, and Joël Querellou for performing the numerical analysis of the $16 \mathrm{~S}$ rRNA sequence data. We thank the captain and crew of N.O. "Le Nadir" and the D.S.V. "Nautile" pilots and support crew.

This work was supported by IFREMER, and Région Bretagne, STA was co-organizer of the French-Japanese Starmer program.

\section{REFERENCES}

1. Antoine, E., G. Barbier, J. C. Caprais, G. Erauso, A. Godfroy, J. Guezennec, D. Prieur, and G. Raguenes. 1991. Isolation and identification of anaerobic sulfur dependent thermophilic bacteria from two new hydrothermal sites in SW Pacific (Lau Basin and North Fiji Basin). Kiel. Meeresforsch. 8:178-181.

2. Balch, W. E., G. E. Fox, L. J. Magrum, C. R. Woese, and R. S. Wolfe. 1979. Methanogens: reevaluation of a unique biological group. Microbiol. Rev. 43:260-296.

3. Belkin, S., and H. W. Jannasch. 1985. A new extremely thermophilic, sulfurreducing heterotrophic marine bacteria. Arch. Microbiol. 141:181-186.

4. Bligh, E. G., and W. J. Dyer. 1959. A rapid method of total lipid extraction and purification. Can. J. Biochem. Physiol. 37:911-917.

5. Blöchl, E., S. Burggraf, G. Fiala, G. Lauerer, G. Huber, R. Huber, R. Rachel, A. Segerer, K. O. Stetter, and P. Völkl. 1995. Isolation, taxonomy and phylogeny of hyperthermophilic microorganisms. World J. Microbiol. Biotechnol. 11:9-16.

6. Blumentals, I. I., M. Itoh, G. J. Olson, and R. M. Kelly. 1990. Role of polysulfides in reduction of elemental sulfur by the hyperthermophilic archaebacterium Pyrococcus furiosus. Appl. Environ. Microbiol. 56:1255-1262.

7. Burggraf, S., H. W. Jannasch, B. Nicolaus, and K. O. Stetter. 1990. Archaeoglobus profundus sp. nov., represents a new species within the sulfate-reducing archaebacteria. Syst. Appl. Microbiol. 13:24-28.

8. Cline, J. D. 1969. Spectrophotometric determination of hydrogen sulfide in natural waters. Limnol. Oceanogr. 14:454-458.

9. Dauga, C., and P. A. D. Grimont. 1991. Nucleotide sequence of 16S rRNA from ten Serratia species. Res. Microbiol. 141:1139-1149.

10. Desbruyères, D., A. M. Alayse-Danet, S. Otha, and the Scientific Parties of Biolau and Starmer Cruises. 1994. Deep-sea hydrothermal communities in southwestern Pacific back-arc basins (the North-Fiji and Lau basins): composition, microdistribution and food web. Mar. Geol. 116:227-242.

11. Erauso, G., A. Godfroy, G. Raguenes, and D. Prieur. Plate cultivation techniques for strictly anaerobic, thermophilic, sulfur-metabolizing Archae. Protocols for archaebacterial research.

12. Erauso, G., A. L. Reysenbach, A. Godfroy, J. R. Meunier, B. Crump, F. Partensky, J. A. Baross, V. Marteinsson, G. Barbier, N. R. Pace, and D. Prieur. 1993. Pyrococcus abyssi sp. nov., a new hyperthermophilic archaeon isolated from a deep-sea hydrothermal vent. Arch. Microbiol. 160:338-349.

13. Fiala, G., and K. O. Stetter. 1986. Pyrococcus furiosus sp. nov. represents a novel genus of marine heterotrophic archaebacteria growing optimally at $100^{\circ} \mathrm{C}$. Arch. Microbiol. 145:56-61.

14. Fiala, G., K. O. Stetter, H. W. Jannasch, T. A. Langworthy, and J. Madon. 1986. Staphylothermus marinus sp. nov, represents a novel genus of extremely thermophilic submarine heterotrophic archaebacteria growing up to $98^{\circ} \mathrm{C}$. Syst. Appl. Microbiol. 8:106-113.

14a.Godfroy, A. Unpublished data.

15. Gonzalez, J. M., C. Kato, and K. Horikoshi. 1995. Thermococcus peptonophilus sp. nov., a fast-growing, extremely thermophilic archaebacterium isolated from deep-sea hydrothermal vents. Arch. Microbiol. 164:159-164.

16. Grimaud, D., J. I. Ishibashi, Y. Lagabrielle, J. M. Auzende, and T. Urabe. 1991. Chemistry of hydrothermal fluids from the $17^{\circ} \mathrm{S}$ active site in the North Fiji Basin ridge (SW Pacific). Chem. Geol. 93:209-218.

17. Hoaki, T., M. Nishijima, M. Kato, K. Adachi, S. Mizobuchi, N. Hanzawa, and T. Maruyama. 1994. Growth requirements of hyperthermophilic sulfurdependent heterotrophic archaea isolated from a shallow submarine geothermal system with reference to their essential amino acids. Appl. Environ. Microbiol. 60:2898-2904.

18. Hoaki, T., C. O. Wirsen, S. Hanzawa, T. Maruyama, and H. W. Jannasch. 1993. Amino acid requirements of two hyperthermophilic archaeal isolates from deep-sea vents, Desulfurococcus sp. strain SY and Pyrococcus sp. strain GB-D. Appl. Environ. Microbiol. 59:610-613.

19. Hobbie, J. E., R. J. Daley, and S. Jasper. 1977. Use of Nuclepore filters for counting bacteria by fluorescence microscopy. Appl. Environ. Microbiol. 33:1225-1228.

20. Huber, R., J. Stöhr, S. Honenhaus, R. Rachel, S. Burggraf, H. W. Jannasch, and K. O. Stetter. 1995. Thermococcus chitonophagus sp. nov., a novel, chitin-degrading, hyperthermophilic archaeum from a deep-sea hydrothermal environment. Arch. Microbiol. 164:255-264.

21. Jannasch, H. W., C. O. Wirsen, S. J. Molyneaux, and T. A. Langworthy. 1988. Extremely thermophilic fermentative archaebacteria of the genus Desulfurococcus from deep-sea hydrothermal vents. Appl. Environ. Microbiol. 54: 1203-1209.

22. Jannasch, H. W., C. O. Wirsen, S. J. Molyneaux, and T. A. Langworthy. 1992. Comparative physiological studies on hyperthermophilic archaea isolated from deep-sea hot vents with emphasis on Pyrococcus sp. strain GB-D. Appl. Environ. Microbiol. 58:3472-3481.

23. Jones, W. J., J. A. Leigh, F. Mayer, C. R. Woese, and R. S. Wolfe. 1983 Methanococcus jannaschii sp. nov., an extremely thermophilic methanogen from a submarine hydrothermal vent. Arch. Microbiol. 136:254-261.

24. Jones, W. J., C. E. Stugard, and H. W. Jannasch. 1989. Comparison of thermophilic methanogens from submarine hydrothermal vents. Arch. Microbiol. 151:314-318.

25. Kates, M. 1964. Bacterial lipids. Adv. Lipid Res. 2:17-90.

26. Keller, M., F.-J. Braun, R. Dirmeieir, D. Hafenbradl, S. Burggraf, R. Rachel, and K. O. Stetter. 1995. Thermococcus alcaliphilus sp. nov., a new hyperthermophilic archaeum growing on polysulfide at alkaline $\mathrm{pH}$. Arch. Microbiol. 164:390-395.

27. Kobayashi, T., Y. S. Kwak, T. Akiba, T. Kudo, and K. Horikoshi. 1994 Thermococcus profundus sp. nov. a new hyperthermophilic archaeon isolated from a deep-sea hydrothermal vent. Syst. Appl. Microbiol. 17:232-236.

28. Kurr, M., R. Huber, H. König, H. W. Jannasch, H. Fricke, A. Trincone, J. K. Kristjansson, and K. O. Stetter. 1991. Methanopyrus kandleri, gen. and sp. nov. represents a novel group of hyperthermophilic methanogens, growing at $110^{\circ} \mathrm{C}$. Arch. Microbiol. 156:239-247. 
29. Langworthy, T. A., G. Holzer, J. G. Zeikus, and T. G. Tornabene. 1983. Isoand anteiso-branched glycerol diethers of the thermophilic anaerobe Ther modesulfotobacterium commune. Syst. Appl. Microbiol. 4:1-17.

30. Marmur, J., and P. Doty. 1962. Determination of the base composition of deoxyribonucleic acid from its thermal denaturation temperature. J. Mol Biol. 5:109-118.

31. Miroshnichenko, M. L., E. A. Bonch-Osmolovskaya, A. Neuner, N. A. Kostrikina, N. A. Chernych, and V. A. Alekseev. 1989. Thermococcus stetteri $\mathrm{sp}$ nov., a new extremely thermophilic marine sulfur-metabolizing archaebacterium. Syst. Appl. Microbiol. 12:257-262.

32. Moensch, T. T., and J. G. Zeikus. 1983. An improved preparation method for a titanium(III) media reductant. J. Microbiol. Methods 1:199-202.

33. Neuner, A., H. W. Jannasch, S. Belkin, and K. O. Stetter. 1990. Thermococcus litoralis sp. nov.: a new species of extremely thermophilic marine archaebacterium. Arch. Microbiol. 153:205-207.

34. Pauly, G. G., and E. S. Van Vleet. 1986. Acyclic archaebacterial ether lipids in swamp sediments. Geochim. Cosmochim. Acta 50:1117-1125.

35. Pledger, R. J., and J. A. Baross. 1989. Characterization of an extremely thermophilic archaebacterium isolated from a black smoker polychaete (Paralvinella sp.) at the Juan de Fuca Ridge. Syst. Appl. Microbiol. 12:249256.

36. Pledger, R. J., and J. A. Baross. 1991. Preliminary description and nutritional characterization of a chemoorganotrophic archaeobacterium growing at temperatures up to $110^{\circ} \mathrm{C}$ isolated from a submarine hydrothermal vent environment. J. Gen. Microbiol. 137:203-211.

37. Pley, U., J. Schipka, A. Gambacorta, H. W. Jannasch, H. Fricke, R. Rachel, and K. O. Stetter. 1991. Pyrodictium abyssi sp. nov. represents a novel heterotrophic marine archaeal hyperthermophile growing at $110^{\circ} \mathrm{C}$. Syst. Appl. Microbiol. 14:245-253.

38. Popoff, M. Y., and C. Coynault. 1980. Use of DEAE cellulose filters in the S1 nuclease method for bacterial deoxyribonucleic acid hybridization. Ann. Inst. Pasteur/Microbiol. (Paris) 131A:151-155.

39. Prieur, D., G. Erauso, and C. Jeanthon. 1995. Hyperthermophilic life at deep-sea hydrothermal vents. Planet. Space Sci. 43:115-121.

40. Rimbault, A., J. Guezennec, M. Fromage, P. Niel, A. Godfroy, and F. Rocchiccioli. 1993. Organic acids and stable isotypes: metabolic studies of thermophilic sulfur-dependent anaerobic archaeon. J. Microbiol. Methods 18:329-338.

41. Saiki, R. K., D. H. Gelfand, S. Stoffel, S. J. Scharf, R. Higuchi, G. T. Horn, K. B. Mullis, and H. A. Erlich. 1988. Primer-directed enzymatic amplification of DNA with a thermostable DNA polymerase. Science 239:487-491.

42. Saitou, M., and M. Nei. 1987. The neighbor-joining method: a new method for reconstructing phylogenetic trees. Mol. Biol. Evol. 44:406-425.

43. Sanger, F., S. Nicklen, and A. R. Coulson. 1977. DNA sequencing with chain-terminating inhibitors. Proc. Natl. Acad. Sci. USA 74:5473-5467.

44. Watrin, L., V. Martin-Jezequel, and D. Prieur. 1995. Minimal amino acid requirements of the hyperthermophilic archaeon Pyrococcus abyssi isolated from deep-sea hydrothermal vents. Appl. Environ. Microbiol. 61:1138-1140.

45. White, D. C., J. D. Nickels, J. D. King, and R. J. Bobbie, 1979. Determination of the sedimentary microbial biomass by extractable lipid phosphate. Oecologia (Berlin) 40:51-62.

46. Zillig, W., I. Holtz, D. Janekovic, W. Schäfer, and W. D. Reiter. 1983. The archaebacterium Thermococcus celer represents a novel genus within the thermophilic branch of the archaebacteria. Syst. Appl. Microbiol. 4:88-94. 